\title{
Widespread presence of cytoplasmic HBcAg in hepatitis B infected liver detected by improved immunochemical methods
}

\author{
EJ GOWANS, CJ BURRELL
}

\begin{abstract}
From the Division of Medical Virology, Institute of Medical and Veterinary Science, Adelaide, South Australia 5000
\end{abstract}

SUMMARY Cytoplasmic and cell membrane associated hepatitis B core antigen ( $\mathrm{HBcAg})$ were found to be more widespread within infected liver using indirect immunofluorescence on frozen sections than with the widely used direct immunofluorescence method. Fixation of frozen sections with carbon tetrachloride improved tissue histology without reducing the sensitivity of antigen detection. In tissue blocks fixed with formalin or ethanol-acetic acid, detection of $\mathrm{HBcAg}$ was reduced in comparison with frozen sections, and many cells containing low concentrations of (usually cytoplasmic and membranous) $\mathrm{HBcAg}$ could not be identified even using indirect immunofluorescence or peroxidase-antiperoxidase reactions. In contrast, intracellular hepatitis B surface antigen ( $\mathrm{HBsAg}$ ) was well detected in fixed sections, but membrane associated $\mathrm{HBsAg}$ was not detectable after fixation.

Among long term carriers of hepatitis B surface antigen, the additional presence of hepatitis $\mathrm{B}$ core antigen ( $\mathrm{HBcAg}$ ) in infected liver tissue is usually assumed to identify those patients in whom appreciable virus replication is occurring. ${ }^{1-4} \mathrm{HBcAg}$ is classically seen within hepatocyte nuclei. Cytoplasmic $\mathrm{HBcAg}$ has also been reported, however, although the significance of different cellular locations remains unknown. ${ }^{56}$ Many carriers with this and other markers of virus replication show a greater tendency for ongoing hepatocyte injury than those carriers without such markers, and $\mathrm{HBcAg}$ has been proposed as a possible immunological target for $T$ cell mediated hepatocyte damage. ${ }^{7}$ This correlation is not absolute, however, and no universal mechanism for hepatocyte injury in such patients has been established. In some livers hepatocytes thought to be supporting hepatitis B virus (HBV) DNA replication often show evidence of cell injury, but cell injury may also be seen in other livers without evidence of viral DNA replication. ${ }^{89}$ Further understanding of the significance of the presence and location of cellular $\mathrm{HBcAg}$, and its relation to virus replication and hepatocyte injury, has been hampered by the insensitivity of the assays used.

Accepted for publication 21 December 1984
HBcAg in infected liver sections has usually been detected by direct immunofluorescence using fluorescein conjugated human anti- $\mathrm{HBc}^{1-4}$; occasionally indirect immunofluorescence or immunoperoxidase assays using human anti-HBc have been used. ${ }^{56}$ The use of the direct test was usually necessary because (a) high titre anti-HBc from an animal species was unavailable and (b) many HBV infected livers contain bound autologous IgG which interferes with the interpretation of results obtained with human anti-HBc.

Recently, $\mathrm{HBcAg}$ has been expressed in Escherichia coli transfected with HBV DNA ${ }^{1011}$ and used to prepare high titre anti-HBc in rabbits. This reagent now permits the ready use of indirect immunofluorescence or peroxidase-antiperoxidase (PAP) reactions for $\mathrm{HBcAg}$ detection. A recently available commercial kit for $\mathrm{HBcAg}$ detection uses this reagent in a peroxidase-antiperoxidase reaction on formalin fixed liver sections. Full comparisons between direct and indirect immunofluorescence and between frozen and fixed tissue sections have not been published.

This report addresses the conflicting demands between, on the one hand, the need for good histological preservation and, on the other hand, the care required to obtain maximum sensitivity of viral antigen detection. 


\section{Patients and methods}

Livers obtained at necropsy from five well documented $\mathrm{HBcAg}$ positive patients with chronic active hepatitis and cirrhosis were included in the study. Samples were removed as soon as possible after death, cut into $2-3 \mathrm{~cm}$ slices, and stored at $-70^{\circ} \mathrm{C}$.

Frozen sections $(6 \mu \mathrm{m})$ were air dried for $15-20$ min, fixed if required, washed in phosphate buffered saline, and stained in a moist chamber at $37^{\circ} \mathrm{C}$ with appropriately diluted reagents. Frozen sections were fixed either by immersion in ethanol-acetic acid (3:1) for $10 \mathrm{~min}$ at room temperature followed by a brief rinse in ethanol and air drying, or by immersion in carbon tetrachloride at $4^{\circ} \mathrm{C}$ for $10 \mathrm{~min}$ and air drying. ${ }^{12}$

From areas of necropsy tissue adjacent to those examined above, tissue blocks, measuring $0.5 \mathrm{~cm}^{3}$, were cut from each liver and fixed either in $10 \%$ buffered formalin for $24 \mathrm{~h}$ or in freshly prepared ethanol-acetic acid (3:1) for $20 \mathrm{~min}$ at room temperature before dehydration and processing into paraffin wax blocks. Sections $(6 \mu \mathrm{m})$ were dried at $37^{\circ} \mathrm{C}$ overnight before use. Before immunostaining the fixed sections were dewaxed in xylene and hydrated. Sections were then stained in a moist chamber at $37^{\circ} \mathrm{C}$ using appropriately diluted reagents.

$\mathrm{HBcAg}$ was detected by (a) a high titre $\mathrm{HBeAg}$ positive, anti-HBc positive human serum directly conjugated to fluorescein isothiocyanate (FITC), diluted $1 / 5$ for use (titre $=320$ by immunofluorescence); or (b) an indirect assay using rabbit anti$\mathrm{HBc}$ serum (Dako Corporation) diluted 1/100 followed by FITC conjugated sheep antirabbit (Wellcome) diluted $1 / 8$; or (c) by the Dako PAP kit system (Dako Corporation) using the manufacturer's recommended protocol. $\mathrm{HBsAg}$ was detected using (a) an indirect immunofluorescence reaction with rabbit anti-HBs (Behringwerke) diluted 1/30 followed by sheep antirabbit FITC (as above) or (b) by PAP performed exactly as for $\mathrm{HBcAg}$ except that the anti-HBs (diluted 1/40) was substituted for anti-HBc in the primary antibody step. All dilutions were in phosphate buffered saline. All reagents used in immunofluorescence reactions were previously absorbed against normal human liver, and the sheep antirabbit FITC was also adsorbed against normal human IgG to remove non-specific cross reactions.

The specificity of each reaction was established using several different uninfected livers as negative controls and, in the case of the indirect assays, by substitution of the first antiserum with a nonimmune serum at the same dilution on infected liver sections.
Our original observations on the five livers were made using the Dako PAP kit to detect $\mathrm{HBcAg}$ as recommended by the manufacturer. In our hands, however, the substrate supplied in the kit, aminoethylcarbazole, produced a reaction product which faded with time, and for this reason subsequent results were obtained using diaminobenzidine $^{13}$ as the substrate. Although the aminoethylcarbazole produced a more aesthetically pleasing and readily recognisable reaction product, we decided that a permanent record of reactions by diaminobenzidine was more desirable.

FITC stained sections were examined in a Ziess microscope equipped with FITC specific Ploem illumination. PAP stained sections were reacted with the aminoethylcarbazole supplied by the manufacturer or with diaminobenzidine and mounted in glycerine jelly or DPX respectively.

\section{Results}

FIXATION OF FROZEN SECTIONS

The detection of $\mathrm{HBsAg}$ and $\mathrm{HBcAg}$ by indirect immunofluorescence in unfixed frozen sections of livers 1 and 2 was compared with results obtained when sequential frozen sections cut from the same block were fixed in ethanol-acetic acid or carbon tetrachloride. Ethanol-acetic acid completely denatured both $\mathrm{HBcAg}$ and $\mathrm{HBsAg}$ so that only a few nuclei showed a weak staining reaction for $\mathrm{HBcAg}$ while $\mathrm{HBsAg}$ was completely negative. Carbon tetrachloride fixed sections, ${ }^{12}$ on the other hand, gave similar staining for $\mathrm{HBsAg}$ and $\mathrm{HBcAg}$ to unfixed sections and resulted in improved histological appearance and better retention of sections on slides (data not shown). Carbon tetrachloride was therefore chosen as a routine fixative for frozen sections. Frozen sections fixed in this manner and stained by indirect immunofluorescence to detect $\mathrm{HBsAg}$ and $\mathrm{HBcAg}$ were then used as the standard to which all subsequent fixation and antigen detection was compared.

DETECTION OF HBcAg BY DIRECT AND INDIRECT IMMUNOFLUORESCENCE

We then examined all five livers for $\mathrm{HBcAg}$ to compare direct and indirect immunofluorescence in carbon tetrachloride fixed, frozen sections. The direct and indirect assays detected nuclear $\mathrm{HBcAg}$ equally well, but cytoplasmic $\mathrm{HBcAg}$ was stained more intensely and was present in a higher number of cells using the indirect method (Fig. 1 and Table 1). Two livers (nos 4 and 5) which showed low concentrations of cytoplasmic $\mathrm{HBcAg}$ in a few cells by direct immunofluorescence now showed low concentrations of cytoplasmic $\mathrm{HBcAg}$ in virtually every 


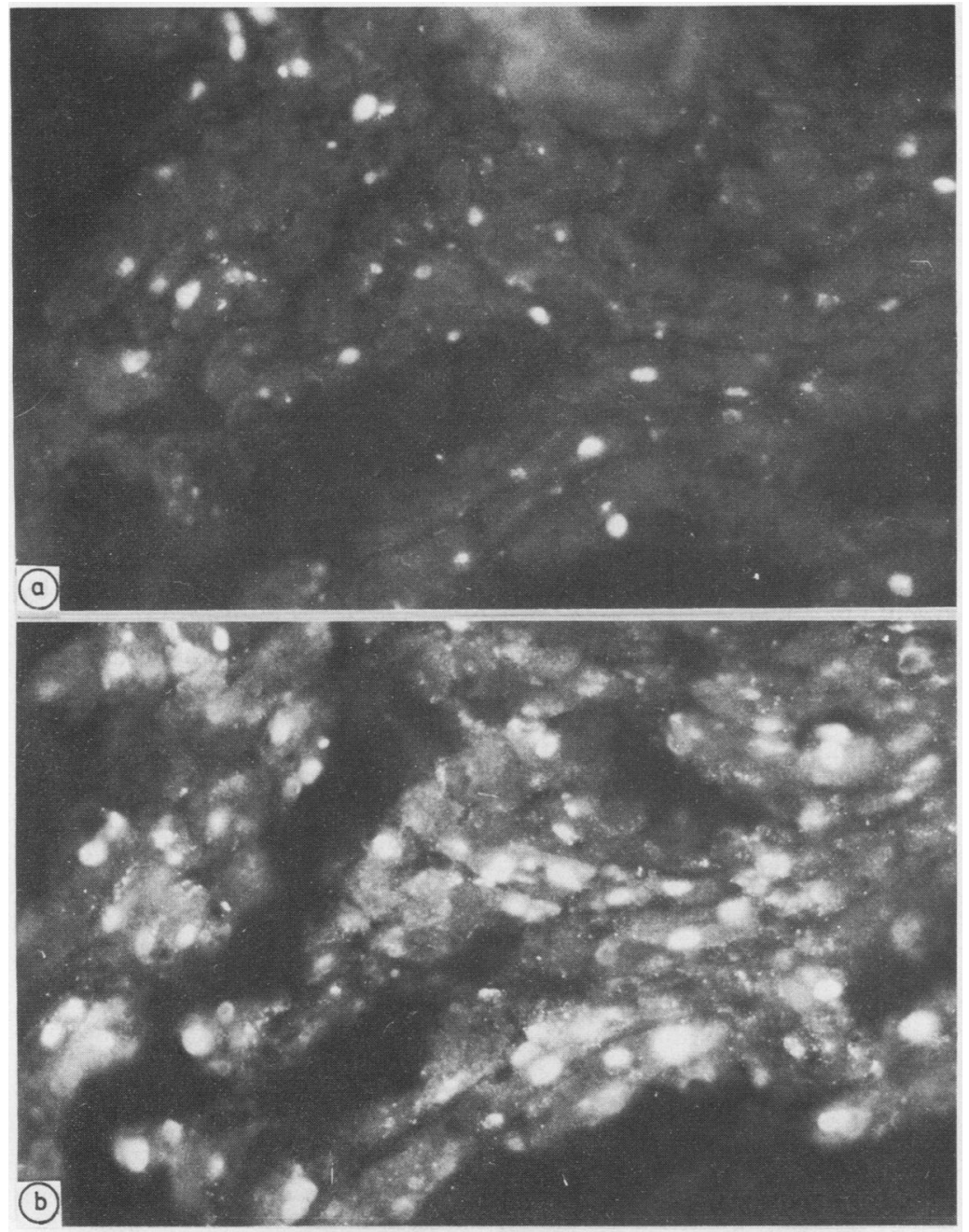

Fig. 1 Comparison of the same field in two sequential frozen sections from liver no 4 stained for $\mathrm{HBCAg}$ by direct immunofuorescence (a) or indirect immunofuorescence (b). (b) was photographed using the camera automatic exposure meter and (a) was subsequently photographed using manual exposure for the same exposure time as (b). $\times 630$.

Table 1 Comparison between direct and indirect immunoftuorescence for $\mathrm{HBcAg}$ on frozen sections subsequently fixed with carbon tetrachloride

\begin{tabular}{|c|c|c|c|c|}
\hline \multirow[t]{3}{*}{ Liver no } & \multicolumn{4}{|l|}{$\boldsymbol{H B C A g}$} \\
\hline & \multicolumn{2}{|l|}{ Nuclear } & \multicolumn{2}{|c|}{ Cytoplasmic* } \\
\hline & Direct & Indirect & Direct & Indirect \\
\hline $\begin{array}{l}1 \\
2 \\
3 \\
4 \\
5\end{array}$ & $\begin{array}{l}++ \\
++ \\
+ \\
+ \\
++++\end{array}$ & $\begin{array}{l}++ \\
++ \\
+ \\
+ \\
++++\end{array}$ & $\begin{array}{l}++ \\
++ \\
++++ \\
\pm \\
\pm\end{array}$ & $\begin{array}{l}+++ \\
+++ \\
++++ \\
++++ \\
++++\end{array}$ \\
\hline
\end{tabular}

*Including membranous $\mathrm{HBcAg}$.

Samples were scored on a $\mathbf{0}-+++$ scale corresponding to 0 , $1-25 \%, 25-50 \%, 50-75 \%$, and $\geqslant 75 \%$ of total hepatocytes examined; in this instance the $0++++$ scale does not represent immunofluorescence intensity. hepatocyte when examined by the indirect immunofluorescence reaction. This was in contrast to nuclear $\mathrm{HBcAg}$, which was detected using both methods in a few foci of cells in liver no 4 and in every hepatocyte in liver no 5. Cytoplasmic $\mathrm{HBcAg}$ detected by indirect immunofluorescence was present as discrete dots throughout the infected cell, occasionally as a large cytoplasmic inclusion, or localised to the cell membrane (Fig. 1b).

\section{DETECTION OF HBsAg IN FROZEN AND FIXED TISSUE BLOCKS}

We then prepared fixed tissue blocks from adjacent areas of tissue to those examined above, using either ethanol-acetic acid or formalin. The results of indirect immunofluorescence or PAP staining for 
Table 2 Detection of HBsAg and HBcAg in (carbon tetrachloride fixed) frozen sections detected by indirect immunofuorescence, compared with peroxidase-antiperoxidase staining in sections from formalin fixed tissue blocks

\begin{tabular}{|c|c|c|c|c|c|c|c|c|}
\hline \multirow[t]{3}{*}{ Liver no } & \multicolumn{4}{|l|}{$H B s A g$} & \multicolumn{4}{|l|}{$H B c A g$} \\
\hline & \multicolumn{2}{|c|}{ Cytoplasmic } & \multicolumn{2}{|c|}{ Membrane } & \multicolumn{2}{|l|}{ Nuclear } & \multicolumn{2}{|c|}{ Cytoplasmic* } \\
\hline & Frozen & $\begin{array}{l}\text { Formalin } \\
\text { fixed }\end{array}$ & Frozen & $\begin{array}{l}\text { Formalin } \\
\text { fuxed }\end{array}$ & Frozen & $\begin{array}{l}\text { Formalin } \\
\text { fixed }\end{array}$ & Frozen & $\begin{array}{l}\text { Formalin } \\
\text { fuxed }\end{array}$ \\
\hline $\begin{array}{l}1 \\
2 \\
3 \\
4 \\
5\end{array}$ & $\begin{array}{l}+ \\
+++ \\
+ \\
+ \\
+\end{array}$ & $\begin{array}{l}+ \\
+++ \\
+ \\
+\end{array}$ & $\begin{array}{l}+++ \\
++ \\
+++ \\
+++ \\
+++\end{array}$ & $\begin{array}{l}- \\
- \\
- \\
-\end{array}$ & $\begin{array}{l}++ \\
++ \\
+ \\
+ \\
++++\end{array}$ & $\begin{array}{l}++ \\
++ \\
- \\
- \\
-\end{array}$ & $\begin{array}{l}+++ \\
+++ \\
++++ \\
+++ \\
++++\end{array}$ & $\begin{array}{l}+++ \\
+++ \\
- \\
- \\
-\end{array}$ \\
\hline
\end{tabular}

${ }^{*}$ Includes membranous $\mathrm{HBcAg}$.

Samples were scored as in Table $1-$ that is, $0-++++$ represents cell numbers and not stäining intensity.

HBsAg on sections from these fixed blocks were then compared with the results obtained by indirect immunofluorescence on carbon tetrachloride fixed, frozen sections.

Indirect immunofluorescence and PAP detected HBsAg in the fixed blocks to a similar extent, although PAP appeared to produce a relatively more intense reaction. Both detection systems showed similar cytoplasmic HBsAg staining in fixed blocks to that seen in carbon tetrachloride fixed, frozen sections (described above), but HBsAg detected at the hepatocyte membrane in fixed frozen sections was undetectable in sections from fixed blocks by either immunofluorescence or PAP (Table 2). This differs from some previous reports that detected membranous HBsAg in formalin fixed tissue $e^{514}$ is but is consistent with other reports, ${ }^{1617}$ where membranous HBsAg was undetected or greatly reduced

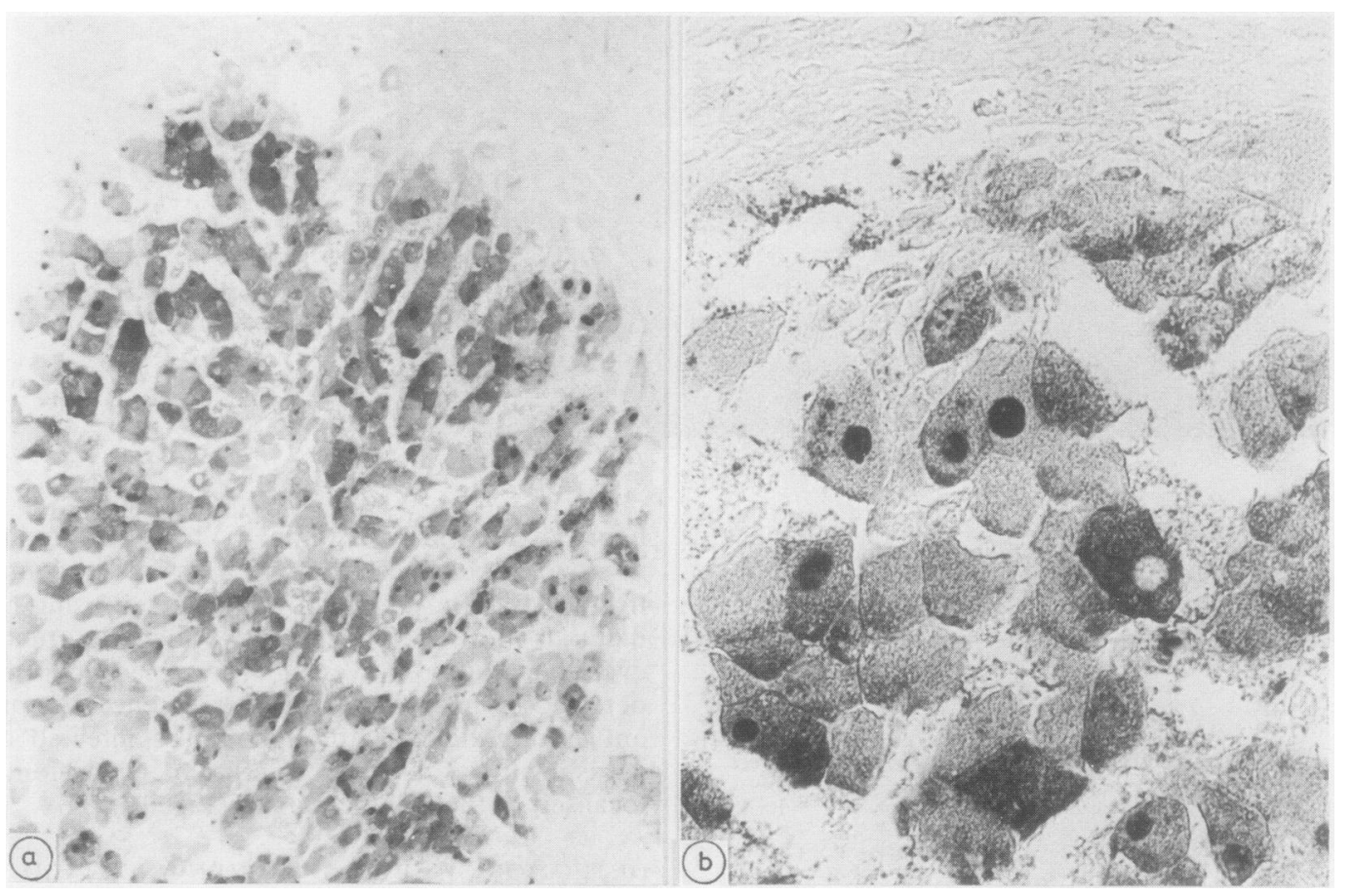

Fig. 2 Section from an ethanol-acetic acid fixed block from liver no 1 . HBcAg was shown by the peroxidase-antiperoxidase reaction using diaminobenzidine as substrate. (a) Low power (100 $\times$ ) and (b) higher power $(400 \times)$ of an infected focus showing $\mathrm{HBcAg}$ in the cytoplasm of the majority of infected cells. The fields were photographed using Kodak Pan-Tech film, and a Kodak Wratten no 58 filter was used to increase contrast. No histological counterstaining was used. 
in formalin fixed tissue. Blocks fixed in formalin were slightly superior for $\mathrm{HBsAg}$ detection to those fixed in ethanol-acetic acid.

\section{DETECTION OF HBcAg IN FROZEN AND FIXED TISSUE BLOCKS}

In contrast to the above $\mathrm{HBsAg}$ results, more cells containing $\mathrm{HBcAg}$ were detected in fixed tissue with PAP than with indirect immunofluorescence, and ethanol-acetic acid was slightly superior to formalin (data not shown). But tissue fixed by either method showed poor detection of $\mathrm{HBcAg}$ present in low concentrations compared with the above results by indirect immunofluorescence on frozen sections. Such low concentrations of $\mathrm{HBcAg}$ were particularly seen in livers nos $3-5$, in which a majority of hepatocytes were $\mathrm{HBcAg}$ positive by indirect immunofluorescence on frozen sections but negative when fixed tissue was examined. Intracytoplasmic $\mathrm{HBcAg}$ detected by PAP in fixed tissue in livers nos 1 and 2 was in general uniformly distributed throughout the cytoplasm and on the cytoplasmic membrane, although a proportion of cells contained a discrete, intensely stained inclusion (Fig. 2) similar to those seen by immunofluorescence.

We attempted to increase the sensitivity of the PAP reaction to detect $\mathrm{HBcAg}$ in formalin fixed livers $3-5$ by substituting the primary anti-HBc reagent (supplied already diluted for use in the kit) with a more concentrated preparation of anti-HBc purchased separately from Dako. No appreciable increase in $\mathrm{HBcAg}$ detection was achieved using a range of higher concentrations of primary anti-HBc. Non-specific reactions were encountered unless the anti-HBc was first absorbed with normal liver homogenate. We concluded that the sensitivity of $\mathrm{HBcAg}$ detection by PAP in formalin fixed sections could not be increased by increasing the primary anti-HBc concentration over that supplied in the commercial kit.

\section{Discussion}

FIXATION OF FROZEN SECTIONS

The detection of $\mathrm{HBsAg}$ and $\mathrm{HBcAg}$ in infected liver tissue is most reliably accomplished in'frozen sections. It is advisable, however, to fix these frozen sections before immunostaining in order to preserve the histological integrity of the tissue. This study showed that carbon tetrachloride retained the antigenicity of $\mathrm{HBsAg}$ and $\mathrm{HBcAg}$ and also preserved the histological appearance. The distribution and concentrations of $\mathrm{HBs} \mathrm{Ag}$ and $\mathrm{HBcAg}$ in infected cells of carbon tetrachloride fixed, frozen sections were then used as the standard to which other fixation methods were compared.
DETECTION OF HBCAg IN FROZEN SECTIONS Comparison of direct with indirect immunofluorescence to detect $\mathrm{HBcAg}$ showed quite clearly that the indirect method was more sensitive. The indirect reaction detected $\mathrm{HBcAg}$ in the cytoplasm of a population of cells previously thought to be negative. for $\mathrm{HBcAg}$ and in some cells which were thought to contain nuclear $\mathrm{HBcAg}$ only. Indeed, in the liver samples studied most $\mathrm{HBcAg}$ positive cells expressed the antigen in the cytoplasm, while nuclear $\mathrm{HBcAg}$ was seen in only a varying proportion of these cytoplasmic $\mathrm{HBcAg}$ positive cells. We do not believe these results are due to leakage of nuclear $\mathrm{HBcAg}$ in these necropsy samples, as we have seen similar $\mathrm{HBcAg}$ distribution patterns in biopsy samples snap frozen within a few minutes of sampling (data not shown).

The significance of this finding is as yet unclear. It is possible that nuclear $\mathrm{HBcAg}$ is not directly involved in virus replication, since nuclei containing $\mathrm{HBcAg}$ detected by immunofluorescence contain little if any virus DNA as shown by us previously using in situ hybridisation." In any case, future studies of the significance of hepatic $\mathrm{HBcAg}$ as an indicator of virus replication and as a possible target for immune cell damage should clearly distinguish nuclear from cytoplasmic $\mathrm{HBcAg}$ and should use a method capable of detecting low concentration, widespread cytoplasmic $\mathrm{HBcAg}$, if present.

\section{DETECTION OF HBsAg AND HBcAg IN FIXED TISSUE}

This part of the study was performed as there were few reports which compared the detection of $\mathrm{HBs} \mathrm{Ag}$ and $\mathrm{HBcAg}$ in fixed tissue with results obtained in frozen sections. Examination of tissue fixed by either of the two methods described indicated that PAP was more sensitive than indirect immunofluorescence. Despite the use of PAP, low concentrations of $\mathrm{HBsAg}$ and $\mathrm{HBcAg}$ (shown to be present, usually at the cell membrane, by indirect immunofluorescence examination of frozen tissue) were undetected in fixed tissue. Other workers have commented on similar results with $\mathrm{HBsAg}^{1819}$ or HBV-unrelated membrane antigens fixed in formalin. $^{20}$ Of the two fixatives studied, formalin was slightly better for $\mathrm{HBsAg}$ detection, and ethanolacetic acid was slightly better for $\mathrm{HBcAg}$ detection. The extent of antigen loss, however, may depend on the time and degree of fixation as well as other less well defined factors, and satisfactory detection of $\mathrm{HBsAg}$ or $\mathrm{HBcAg}$ should not be assumed after any type of fixation without proper evaluation.

\section{CONCLUSIONS}

Three main points have emerged from this study: 
1 Cytoplasmic $\mathrm{HBcAg}$ is much more abundant in HBV infected liver tissue than was previously demonstrable.

$2 \mathrm{HBV}$ infected liver tissue fixed and processed into paraffin wax may fail to show the same pattern of HBV antigen expression seen in frozen sections of the same liver. This is particularly true of viral antigens expressed on the cytoplasmic membrane of infected hepatocytes.

3 Studes relating $\mathrm{HBcAg}$ expression with virus replication or hepatocyte injury should allow for the above and should clearly distinguish nuclear and cytoplasmic $\mathrm{HBcAg}$ localisation in view of their possibly differing significance.

This work was supported by a grant from the National Health and Medical Research Council of Australia and carried out in a category 1 laboratory with approval from the Institute of Medical and Veterinary Science Biohazard Committee. We thank Allison Jilbert and Tom MacNaughton for helpful discussion, Judy Findlay for skilled technical assistance, Nancy Mitchell and Deloraine Mauviel for typing, and the staff of the gastroenterology laboratory, IMVS, for a constant supply of sections.

\section{References}

' Gudat F, Bianchi L, Sonnabend W, Thiel G, Aenishaenslin W, Stalder GA. Pattern of core and surface expression in liver tissue reflects state of specific immune response in hepatitis B. Lab Invest 1975; 32:1-9.

${ }^{2}$ Ray MB, Desmet VJ, Bradburne AF, Desmyter J, Fevery J, De Groote J. Differential distribution of hepatitis B surface antigen and hepatitis B core antigen in the liver of hepatitis B patients. Gastroenterology 1976;71:462-7.

${ }^{3}$ Hadziyannis SJ', Lieberman HM, Karvountzis GB, Shafritz DA. Analysis of liver disease, nuclear $\mathrm{HBcAg}$, viral replication, and hepatitis $B$ virus DNA in liver and serum of $\mathrm{HBcAg}$ vs. anti$\mathrm{HBe}$ positive carriers of hepatitis $\mathrm{B}$ virus. Hepatology 1983;3:656-62.

${ }^{4}$ Bonino F, Hoyer B, Nelson J, Engle R, Verme G, Gerin J. Hepatitis $B$ virus DNA in the sera of $\mathbf{H B s A g}$ carriers: a marker of active hepatitis $B$ virus replication in the liver. Hepatology 1981; 1:386-91.

${ }^{5}$ Huang SN, Neurath AR. Immunohistologic demonstration of hepatitis B viral antigens in liver with reference to its significance in liver injury. Lab Invest 1979;40:1-17.

- Yamada G, Nakane PK. Hepatitis B core and surface antigens in liver tissue. Light and electron microscopic localisation by the peroxidase-labelled antibody method. Lab Invest 1977; 36:649-59.

' Eddleston ALWF, Mondelli M, Mieli-Vergani G, Williams R. Lymphocyte cytotoxicity to autologous hepatocytes in chronic hepatitis B virus infection. Hepatology 1982;2:122S-7S.

${ }^{8}$ Burrell CJ, Gowans EJ, Rowland R, Hall P, Jilbert AR, Marmion BP. Correlation between liver histology and markers of hepatitis B virus replication: A study by in situ hybridisation. Hepatology 1984;4:20-4.

' Gowans EJ, Burrell CJ, Jilbert AR, Marmion BP. Patterns of single- and double-stranded hepatitis B virus DNA and viral antigen accumulation in infected liver cells. J Gen Virol 1983;64:1229-39.

${ }^{10}$ Burrell CJ, Mackay P, Greenaway PJ, Hofschneider PH, Murray $\mathrm{K}$. Expression in Escherichia coli of hepatitis B virus DNA sequences cloned in plasmid pBR322. Nature (London) 1979;279:43-7.

"Stahl S, Mackay P, Magazin M, Bruce SA, Murray K. Hepatitis B virus core antigen: Synthesis in Eschericha coli and application in diagnosis. Proc Natl Acad Sci USA 1982;79:1606-10.

${ }^{12}$ Watanabe M, Umenai T, Chori H, Ishida N. Evidence for the multiplication of hepatitis $\mathrm{B}$ virus in 'oval cell' culture originated from human embryonic liver. Br $J$ Exp Pathol 1976;57:211-6.

${ }^{13}$ Graham RC, Karnovsky MJ. The early stages of adsorption of infected horseradish peroxidase in the proximal tubules of mouse kidney: ultrastructural cytochemistry by a new technique. J Histochem Cytochem 1966;14:291-302.

${ }_{14}$ Burns J. Immunoperoxidase localisation of hepatitis B antigen in formalin-paraffin processed liver tissue. Histochemistry 1975;44:133-5.

's Tedder RS, Guarascio P, Yao JL, Lord RB, Eddleston ALWF. Production of monoclonal antibodies to hepatitis B surface and core antigens and use in the detection of viral antigens in livers biopsies. J Hyg (Camb) 1983;90:135-42.

${ }^{16}$ Tapp E, Jones DM. HBsAg and HBcAg in the livers of asymptomatic hepatitis B antigen carriers. J Clin Pathol 1977; 30:671-7.

${ }^{17}$ Blenkinsopp WK, Haffenden GP. Aetiology of cirrhosis, hepatic fibrosis and hepatocellular carcinoma. J Clin Pathol 1977; 30:579-84.

${ }^{18}$ Ray MB. Hepatitis B virus antigens in tissues. Baltimore: University Park Press, 1979.

${ }^{14}$ Kringshohn B, Moller AM, Praetorius Clausen P, Mathieson LR. Methods for localisation of hepatitis B surface antigen in liver tissue. An evaluation of different staining - and tissue preparation methods. Acta Path Microbiol Immunol Scand $[A]$ 1983;91:329-34.

${ }^{20}$ Hsu SM, Zhang H-Z, Jaffe ES. Utility of monoclonal antibodies directed against $B \& T$ lymphocytes and monocytes in paraffin-embedded sections. Am J Clin Pathol 1983;80:41520.

Requests for reprints to: Dr CJ Burrell, Division of Medical Virology, Institute of Medical and Veterinary Science, PO Box 14 Rundle Mall PO, Adelaide SA 5000, Australia. 